\title{
ANALISIS PENDAPATAN DAN KELAYAKAN USAHA TANI JAGUNG HIBRIDA (Zea mays L) DI DESA BUMI HARJO KABUPATEN KOTAWARINGIN BARAT
}

\author{
Revenue Analysis and Feasibility of Hybrid Corn Farming (Zea mays L) in Bumi Harjo \\ Village, West Kotawaringin Regency
}

\section{Shofiyah*}

Universitas Antakusuma,

Pangkalan Bun, Central

Kalimantan, Indonesia

*email:

shofiyah.untama@gmail.com

\begin{abstract}
Abstrak
Desa Bumi Harjo, Kecamatan Kumai merupakan salah satu desa yang mengalami perkembangan dalam bidang pertanian. Petani Desa Bumi Harjo melakukan usaha tani jagung hibrida. Tujuan dari penelitian ini adalah: untuk mengetahui pendapatan, dan kelayakan usaha tani jagung hibrida di Desa Bumi Harjo serta mengetahui prospek perkembangan usahanya. Metode analisis data yang digunakan untuk mengetahui pendapatan dan kelayakan menggunakan rumus uji-t dan rumus korelasi pearson untuk mengetahui tingkat hubungan antar variabel. Hasil penelitian menunjukan bahwa rata-rata pendapatan yang diterima petani responden adalah sebesar 2.089.917/ha, dan usaha tani jagung hibrida di Desa Bumi Harjo layak untuk dijalankan dengan nilai R/C ratio > I yaitu 7,I. Berdasarkan uji $-\mathrm{t}$ di ketahui korelasi antara pendapatan dengan luas lahan diperoleh $\mathrm{t}$ hitung $=$ $9,346>t$ table $=2,052$ yang arti nya terdapat hubungan yang kuat, yakni semakin besar luas lahan akan semakin tinggi hasil pendapatan yang diperoleh. Sedangkan prospek perkembangannya cukup baik dilihat dari peningkatan jumlah populasi hewan ternak pada tahun 2013 dengan kebutuhan pakan ternak mencapai 2.183 ton per bulan dengan demikian usaha tani jagung hibrida bisa jadi rekomendasi untuk usaha yang berkelanjutan.
\end{abstract}

\section{Kata Kunci:}

Jagung Hibrida

Pendapatan Usaha Tani

Pelayakan Usaha Tani

\section{Keywords: \\ Hybrid Corn \\ Farming Income \\ Farming Feasibility}

Accepted

March 2019

\section{Published}

June 2019

\begin{abstract}
Bumi Harjo Village, Kumai District is one of the villages that has experienced developments in agriculture. Bumi Harjo Village farmers do hybrid corn farming. The objectives of this study were: to find out the income, and the feasibility of hybrid corn farming in Bumi Harjo Village and to know the prospects for the development of its business. The data analysis method used to determine income and feasibility using the $t$ test and Pearson correlation formula to determine the level of relationships between variables. The results showed that the average salary received by respondent farmers was 2,089,917/ha, and hybrid maize farming in Bumi Harjo Village was feasible to run with an $R / C$ ratio $>$ I which was $7 . I$. Based on the $t$-test it was found that the correlation between income and land area obtained $t$ count $=9,346>t$ table $=2,052$ which means that there is a strong relationship, namely the more significant the land area, the higher the income earned. While the prospect of development is quite good, seen from the increase in the number of livestock populations in 2013 with animal feed needs reaching 2,183 tons per month, thus hybrid corn farming can be a recommendation for sustainable business.
\end{abstract}

\section{PENDAHULUAN}

Negara Indonesia merupakan negara agraris dimana sektor pertanian menjadi sektor utama dalam membangun perekonomian Indonesia. Selain sebagai penyedia bahan pangan, sektor pertanian membantu dalam menciptakan lapangan kerja juga sebagai salah satu sumber penghasil devisa negara (Rompas et al., 20I5). Dari tahun ke tahun permintaan akan bahan pangan di Indonesia semakin meningkat khususnya bahan pangan utama karbohidrat seperti padi, jagung, dan kedelai (Ariani, 2015). Tanaman jagung merupakan komoditas penting kedua setelah padi, yang sangat bermanfaat bagi manusia maupun hewan. Selain dimanfaatkan sebagai bahan pangan, jagung juga dapat dimanfaatkan untuk pakan ternak, maupun bahan baku industri (Purwanto et al., 20I5).

Beberapa tahun belakangan ini budidaya jagung hibrida di Kotawaringin Barat mengalami penurunan. 
Pengembangan usahatani tanaman jagung hibrida di Kotawaringin Barat memiliki beberapa permasalahan, seperti rendahnya produktivitas usahatani karena keterbatasan lahan dan keahlian yang dimiliki petani, kurangnya modal untuk pembelian sarana produksi terutama untuk pembelian benih, pupuk, dan obat obatan yang harganya terus mengalami meningkat (Muhdiar, 2016; Susilawati et al., 2015). Hal ini berakibat pada menurunya tingkat perkembangan produksi tanaman jagung setiap tahun, dimana luas panen tanaman jagung dari tahun 201I-2013 mengalami penurunan sebagaimana ditampilkan pada Tabel I.

Tabel I. Luas Panen dan Produksi Jagung

\begin{tabular}{cccccc}
\hline & Uraian & Satuan & $20 \mathrm{II}$ & 2012 & 2013 \\
\hline \multirow{2}{*}{ Jagung } & Luas panen & $(000) \mathrm{Ha}$ & $\mathrm{I}, 20$ & 0,72 & 0,40 \\
& produksi & $(000) \mathrm{Ha}$ & 4,09 & 2,48 & $\mathrm{I}, 48$ \\
\hline
\end{tabular}

Sumber: Badan Pusat Statistik Kotawaringin Barat Tahun 2014

Adapun peluang bisnis untuk jagung hibrida di Kotawaringin Barat cukup baik. Hal ini terkait dengan kebutuhan pakan ternak, dimana untuk wilayah Kotawaringin Barat jumlah populasi hewan ternak yang pakannya sering menggunakan jagung seperti ayam buras, ayam pedaging, dan itik mengalami peningkatan dari tahun 201 I-2013 sebagaimana Tabel 2 berikut.

Tabel 2. Data Ternak dengan Pakan Jagung di Kabupaten Kotawaringin Barat

\begin{tabular}{cccc}
\hline \multirow{2}{*}{ Tahun } & \multicolumn{3}{c}{ Jumlah Populasi (Ekor) } \\
\cline { 2 - 4 } & Ayam Buras & Ayam Pedaging & Itik \\
\hline 2011 & 278.597 & 149.601 & 35.706 \\
2012 & 315.121 & 157.466 & 38.055 \\
2013 & 342.230 & 163.699 & 39.708 \\
\hline
\end{tabular}

Sumber: Badan Pusat Statistik Kotawaringin Barat Tahun 2014

Meningkatnya jumlah hewan ternak, membuka peluang untuk mengembangkan dan meningkatkan usahatani jagung hibrida sebagai pakan ternak (Hasan et al., 2016). Karena itu, perlu dilakukan penelitian tentang bagaimana hubungan luas lahan dan biaya terhadap pendapatan usahatani jagung hibrida serta kelayakan usahataninya di Desa Bumi Harjo Kecamatan Kumai Kabupaten Kotawaringin Barat, dimana petaninya melakukan budidaya jagung hibrida tersebut. Adapun tujuan dari penelitian, yakni untuk mengetahui kelayakan usaha jagung hibrida sebagai langkah awal untuk bahan pertimbangan dalam budidaya dan pengembangan usaha tani jagung hibrida di Desa Bumi Harjo Kecamatan Kumai Kabupaten Kotawaringin Barat.

\section{METODOLOGI}

Pada penelitian diperlukan data kualitatif dan kuantitatif, dimana data diperoleh melalui responden terpilih dengan cara mengajukan pertanyaan-pertanyaan yang teah disusun dalam kuesioner yang telah disediakan. Selain itu, data juga diperoleh melalui studi literatur untuk mendukung dan memperkuat data primer yang telah diperoleh dari responden. Fokus utama dalam penelitan ini adalah petani yang melakukan usahatani jagung hibrida di wilayah Desa Bumi Harjo dengan luasan lahan yang mencukupi untuk usaha yakni 0,25I,00 hektar.

Pengumpulan data dalam penelitian ini dilakukan dengan menggunakan tiga teknik, yakni:

I. Observasi; merupakan kegiatan yang dilakukan untuk memperoleh data yang valid dan memperoleh gambaran yang jelas, dimana pengamatan dan pengukuran langsung di lapangan.

2. Wawancara; merupakan kegiatan untuk memperoleh data secara langsung dari responden dengan mengajukan pertanyaan yang telah disipkan dalam daftar kueisioner.

3. Dokumentasi merupakan teknik pengumpulan data yang diperoleh dari berbagai literatur seperti berbentuk surat, catatan harian, arsip foto, hasil rapat, buku dan lain sebagainya

Metode analisis yang digunakan untuk menjawab permasalahan yang ada adalah:

I. Analisis pendapatan menurut Soekartawi (2006), dihitung dengan menggunakan rumus, sebagai berikut:

a. Biaya/Pengeluaran; $\mathbf{T C}=\mathbf{F C}+\mathbf{V C}$,

$\mathrm{TC}=$ Total cost 
$\mathrm{FC}=$ Fix cost

$\mathrm{VC}=$ Variable cost

b. Penerimaan; $\mathbf{T R}=\mathbf{Y} . \mathbf{P y}$

$\mathrm{TR}=$ total penerimaan $($ Total revenue)

$Y=$ produksi suatu usahatani

Py = Harga $Y$

c. Pendapatan; $\mathbf{P d}=\mathbf{T R}-\mathbf{T C}$

Pd = Pendapatan usahatani

$\mathrm{TR}=$ Total penerimaan (Total revenue)

$\mathrm{TC}=$ Biaya total $($ Total cost $)$

2. Analisis kelayakkan menurut Soekartawi (2006), dihitung dengan menggunakan rumus sebagai berikut:

\section{$\mathrm{R} / \mathrm{C}$ ratio $=\mathrm{TR} / \mathrm{TC}$}

Dengan kriteria:

a. R/C > I, usahatani menguntungkan (tambahan penerimaan lebih besar dari tambahan biaya),

b. R/C < I, usahatani rugi (tambahan biaya lebih besar dari tambahan penerimaan,

c. $R / C=I$, usahatani impas (tambahan penerimaan sama besar dengan tambahan biaya).

3. Analisis Korelasi dan Uji Signifikansi Koefisien Korelasi (Uji-t)

Menurut Trihendradi (2007) analisis korelasi digunakan untuk mencari derajat keeratan hubungan dan arah hubungan. Nilai korelasi berada dalam rentang 0 sampai I atau 0 sampai $-\mathrm{I}$. Tanda positif dan negative menandakan arah hubungan, dimana nilai semakin mendekati I atau - I berarti hubungan antara dua variabel semakin kuat, sebaliknya nilai mendekati 0 berarti hubungan antara dua variabel semakin lemah. Nilai korelasi (r) sering juga disebut koefisien korelasi.

Menurut Sugiyono (2007) pedoman umum dalam menentukan kriteria korelasi sebagaimana tercantum pada Tabel 3. Sedangkan uji signifikansi koefisien korelasi digunakan untuk menguji apakah hubungan yang terjadi berlaku atau tidak (Trihendradi, 2007).

Tabel 3. Kriteria Tingkat Korelasi

\begin{tabular}{cc}
\hline Rentang Nilai & Tingkatan korelasi \\
\hline $0,00-0,199$ & sangat rendah \\
$0,20-0,399$ & rendah \\
$0,40-0,599$ & sedang \\
$0,60-0,799$ & kuat \\
$0,80-1,00$ & sangat kuat
\end{tabular}

Sumber: Sugiyono, 2007

\section{HASIL DAN PEMBAHASAN}

Analisis Pendapatan dan Kelayakkan Usahatani Jagung Hibrida

Pendapatan dan kelayakan yang dihitung dalam penelitian ini merupakan hasil perhitungan per satu kali produksi (satu musim). Adapun hasil dari perhitungan pendapatan dan kelayakan usahatani jagung hibrida di Desa Bumi Harjo dapat dilihat pada Tabel 4 berikut ini. Berdasarkan tabel 4. di atas menunjukkan bahwa pendapatan rata-rata petani jagung hibrida satu kali panen selama tiga bulan di Desa Bumi Harjo, Kecamatan Kumai Kabupaten Kotawaringin Barat sebesar Rp. 2.089.917,- Adapun rata-rata jumlah penerimaan sebesar Rp. 2.453.333,- dan rata-rata jumlah biaya yang dikeluarkan sebesar Rp. 363.4I7,-. Analisis R/C ratio merupakan perbandingan antara total penerimaan dan biaya. Hasil perhitungan untuk analisis R/C ratio usahatani jagung hibrida di Desa Bumi Harjo diperoleh nilai sebesar 7.I. Berdasarkan kriteria kelayakan usaha disebutkan bahwa, jika nilai R/C ratio > I artinya usaha usahatani tersebut layak untuk dilanjutkan dan dikembangkan sebagai suatu usahatani.

Tabel 4. Total Biaya, Penerimaan, Pendapatan dan R/C Ratio Petani Jagung Hibrida Berdasarkan Luas Lahan

\begin{tabular}{ccrc}
\hline Uraian & & Nilai Rata-rata (Rp) & R/C \\
\hline Luas lahan tiap & TC & 363.417 & $7, \mathrm{I}$ \\
responden 0,25 & TR & 2.453 .333 & (R/C > I; = \\
Ha & Pd & 2.089 .917 & layak) \\
\hline Keterangan: TC: & Total cost; TR: Total Revenue; Pd: Pendapatan
\end{tabular}
usahatani; R/C: Revenue/Cost 
Nilai analisis untuk kelayakan usaha jagung hibrida dapat menjadi dasar untuk kelanjutan dan perkembangan budidaya jagung hibrida. Berdasarkan hasil pengamatan dan data di lapangan menunjukan adanya peningkatan usaha ternak (Tabel 2) yang dapat menggunakan pakan bersumber dari jagung hibrida ini. Saat ini diketahui kebutuhan pakan ternak mencapai 2.183 Ton per bulan yang berasal dari jagung. $\mathrm{Hal}$ ini menjadi peluang tersendiri bagi petani untuk meningkatkan produksi jagung hibrida.

Korelasi antara Biaya Produksi, Pendapatan dan Luas Lahan

Sebelumnya dilakukan dilakukan analisis untuk korelasi, maka perlu diketahui terlebih dahulu nilai dari uji-t. Ujit dilakukan dengan tujuan untuk mengetahui ada atau tidaknya hubungan antara pendapatan dengan luas lahan ataupun hubungan pendapatan dengan biaya. Adapun hasil perhitungan uji-t dapat dilihat pada Tabel 5 berikut. Berdasarkan perhitungan uji-t diketahui bahwa nilai $t$ hitung pendapatan dengan luas lahan diperoleh nilai sebesar 9, 346 dan $\mathrm{t}$ tabel sebesar 2, 052. Hal ini menunjukkan bahwa nilai $\mathrm{t}$ hitung $>\mathrm{t}$ tabel yang artinya terdapat hubungan antara pendapatan dengan luas lahan, dimana semakin besar luas lahan maka akan semakin tinggi pendapatan. Demikian pula pada hitungan uji-t untuk pendapatan dengan biaya bahwa nilai $t$ hitung pendapatan diperoleh nilai sebesar 3,040 dan t tabel sebesar 2, 052. Hal ini menunjukkan terdapat hubungan yang signifikan (nilai $t$ hitung $>\mathrm{t}$ tabel).

Tabel 5. Hasil Uji-t

\begin{tabular}{ccc}
\hline Variabel & t hitung & t tabel \\
\hline Pendapatan dengan luas & 9,346 & 2,052 \\
Pendapatan dengan biaya & 3,040 & 2,052 \\
\hline
\end{tabular}

Hasil uji-t di atas diperkuat dengan analisis korelasi pearson yang menggambarkan keterikatan hubungan diantara ketiga variabel tersebut. Hasil korelasi pearson dapat dilihat pada tabel 6 dan 7. Berdasarkan Tabel 6. tampak bahwa terjadi hubungan yang sangat kuat antara pendapatan dengan luas lahan. Hal ini ditunjukan pada nilai yang dimiliki $r$, yakni mendekati + I yaitu sebesar 0,897 (terdapat hubungan yang signifikan). Tanda positif
(+) mempunyai arti bahwa korelasi yang terjadi adalah hubungan yang berbanding lurus, dimana semakin luas lahan yang digunkan untuk usahatani maka semakin tinggi pendapatan yang akan diperoleh. Selain itu, berdasarkan data dan hasil wawancara diketahui bahwa dalam usahatani jagung petani menggunakan pupuk kandang dan pestisida untuk meningkatkan hasil produksi. Beberapa petani (6 orang) yang menggunakan pupuk kandang dan pestisida secara teratur memiliki nilai kelayakan ( $R / C$ ratio) yang tinggi, yakni $\geq 8$.

Tabel 6. Hasil Korelasi Pearson antara Pendapatan dengan Luas Lahan

\begin{tabular}{|c|c|c|c|}
\hline & & Pendapatan & Luas \\
\hline \multirow[t]{3}{*}{ Pendapatan } & Pearson Correlation & I &, $897(* *)$ \\
\hline & Sig (2-tailed) & & ,000 \\
\hline & $N$ & 30 & 30 \\
\hline \multirow[t]{3}{*}{ Luas } & Pearson Correlation & ,897(**) & I \\
\hline & Sig (2-tailed) & ,000 & \\
\hline & $\mathrm{N}$ & 30 & 30 \\
\hline
\end{tabular}

Adapun hubungan pendapatan dengan biaya berdasarkan analisis korelasi pearson diperoleh hasil sebagaimana Tabel 7. Berdasarkan Tabel 7. tampak bahwa terjadi hubungan yang kuat antara pendapatan dengan biaya. Hal ini ditunjukan pada nilai yang dimiliki $r$, yakni sebesar 0,617, sebagaimana kriteria untuk korelasi menurut Sugiyono (2007), dimana rentang nilai 0,60 - 0,799 menunjukan tingkatan korelasi adalah kuat. Dilihat dari data di lapangan dan hasil wawancara terhadap responden tentang penggunaan pupuk kandang yang mempengaruhi pada penambah biaya tetapi juga menaikan produksi. Pemberian pupuk kandang yang berkelanjutan, dalam jangka panjang akan membantu dalam membangun kesuburan tanah. Hal ini sejalan dengan pendapat Budiman (2013) yang menyebutkan bahwa pupuk kandang adalah pupuk yang berasal dari kotoran hewan yang berperan untuk memacu pertumbuhan dan perkembangan bakteri dan makhluk tanah lainnya. Penjelasan di atas menunjukan bahwa hubungan antara pendapatan dengan luas lahan lebih besar pengaruhnya dibandingkan dengan hubungan antara pendapatan dengan biaya. 
Tabel 7. Hasil Korelasi Pearson antara Pendapatan dengan Biaya

\begin{tabular}{llrr}
\hline & Pendapatan & \multicolumn{1}{c}{ Luas } \\
\hline Pendapatan & Pearson Correlation & $\mathrm{I}$ &, $617\left({ }^{* *}\right)$ \\
& Sig (2-tailed) & 30 &, 000 \\
\multirow{4}{*}{ Luas } & $\mathrm{N}$ & 30 \\
& Pearson Correlation &, $617(* *)$ & $\mathrm{I}$ \\
& Sig (2-tailed) &, 000 & \\
N & 30 & 30 \\
\hline ** Correlation is significant at the 0,0I level (2-tailed)
\end{tabular}

\section{KESIMPULAN}

Berdasarkan uraian di hasil dan pembahasan, maka dapat diambil kesimpulan bahwa Pendapatan rata-rata yang diperoleh petani jagung di Desa Bumi Harjo sebesar Rp. 2.089.9/7/0,25 Ha atau Rp. 8.359.668/Ha. Usahatani jagung hibrida di Desa Bumi Harjo layak untuk dilanjutkan dan dikembangkan berdasarkan hasil analisis kelayakan usaha, dimana nilai $R / C$ sebesar $7, I$. Berdasarkan hasil uji t diketahui terdapat hubungan yang positif, baik antara pendapatan dengan luas lahan $(\mathrm{t}$ hitung $=9,346>t$ tabel $=2,052$ ) ataupun pendapatan dengan biaya $(\mathrm{t}$ hitung $=3,040>\mathrm{t}$ tabel $=2,052)$. Hasil korelasi pearson menunjukan tingkat kekuatan hubungan antar variabel (pendapatan dengan luas lahan maupun pendapatan dengan biaya).

\section{REFERENSI}

Ariani, M. 2015. Dinamika Konsumsi Beras, Jagung dan Kedelai Mendukung Swasembada Pangan. In Memperkuat Pembangunan Swasembada Pangan. Jakarta: Indonesian Agency for Agricultural Research and Development Press.

Badan Pusat Statistik Kotawaringin Barat. 2014. Statistik Daerah Kabupaten Kotawaringin Barat 20/4. Pangkalan Bun: Badan Pusat Statistik Kotawaringin Barat.

Hasan, H., Laapo, A., \& Rauf, R.A. 2016. Analisis Pendapatan dan Strategi Pengembangan Usahatani Jagung Hibrida di Kecamatan Labuan Kabupaten Donggala. Agroland: Jurnal IImu-IImu Pertanian, 23, 26-39.

Muhdiar, M. 2016. Tingkat Penerapan Agribisnis pada Usahatani Jagung Hibrida di Desa Sipatuo Kecamatan Patampanua Kabupaten Pinrang. Jurnal Galung Tropika, 5, 191-202.
Purwanto, A.Z.A., Hadayani, \& Muis, A. 20I5. Analisis Produksi dan Pendapatan Usahatani Jagung Hibrida di Desa Modo Kecamatan Bukal Kabupaten Buol. Agroland: Jurnal IImu-Ilmu Pertanian, 22, 205-2I 5.

Rompas, J., Engka, D., \& Tolosang, K. 20I5. Potensi Sektor Pertanian dan Pengaruhnya Terhadap Penyerapan Tenaga Kerja di Kabupaten Minahasa Selatan. Efisiensi, 4, I24-I36.

Soekartawi. 2006. Analisis Usahatani. Jakarta: Universitas Indonesia Press.

Sugiyono. 2007. Statistika Untuk Penelitian. Bandung: Alfabeta.

Susilawati, Yudiono, S., \& Suyatno, A. 2015. Analisis Efisiensi Alokatif Faktor-Faktor Produksi Usahatani Jagung Hibrida di Kawasan Usaha Agribisnis Terpadu (Kuat) Rasau Jaya Komplek Kabupaten Kubu Raya. Jurnal Social Economic of Agriculture, 4, 88-102.

Trihendradi, C. 2007. Statistik Inferen Menggunakan SPSS. Yogyakarta: Andi Offset. 